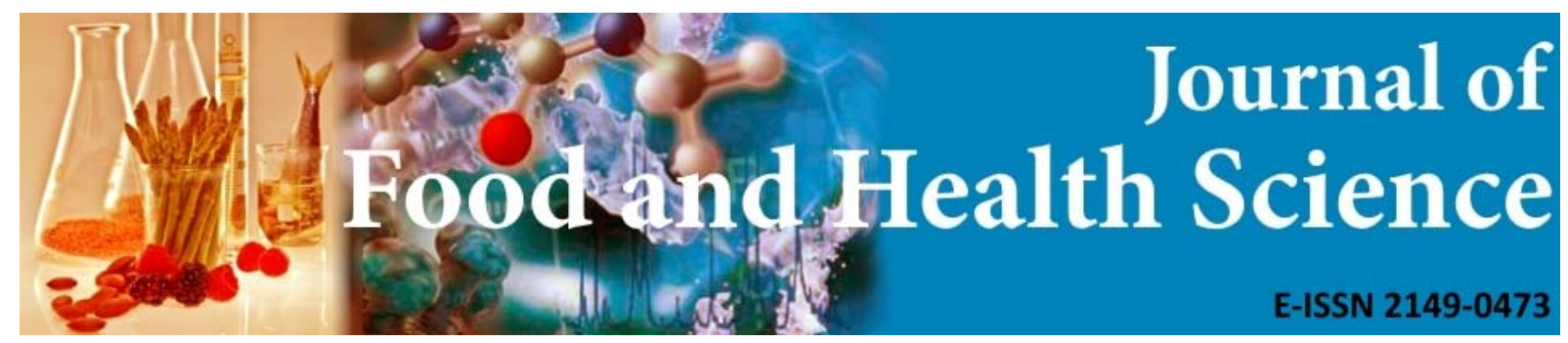

ORIGINAL ARTICLE/ORİJİNAL ÇALIŞMA

TAM MAKALE

\title{
DOES THE REALISTIC CONTACT AND DAILY USE CONDITIONS LIMIT THE USE OF POLYCARBONATE BABY BOTTLES FOR MIGRATION AND RESIDUE LEVEL OF BISPHENOL-A
}

\author{
Özlem Kızılırmak Esmer ${ }^{1}$ ORCID ID: 0000-0003-4652-0514, Özlem Çağındı ${ }^{2}$ ORCID ID: 0000-0002- \\ 6436-9208, Büşra Şahin ${ }^{1}$ ORCID ID: $\underline{0000-0002-5017-5760}$ \\ ${ }^{1}$ Department of Food Engineering, Ege University, Bornova, Izmir, Turkey \\ ${ }^{2}$ Department of Food Engineering, Manisa Celal Bayar University, Muradiye, Manisa, Turkey
}

Received: $15.02 . .2017$

Accepted: 21.06 .2017

Published online: 22.09.2017
Corresponding author:

Özlem Kızılırmak Esmer, Department of Food Engineering, Ege University, Bornova, Izmir, Turkey

E-mail: ozlem.kizilirmak@ege.edu.tr

\begin{abstract}
:
Bisphenol-A (BPA) which is a plastic monomer acting as endocrine disruptor, can cause developmental effects and change the metabolism even at low concentrations. This study was carried out to make (i) a general assessment by performing residue analysis on the polycarbonate baby bottles, (ii) determining the factors affecting the migration of BPA to the food and (iii) determining the effect of repetitive procedures on PC baby bottles in daily use. Amount of residual BPA ranged from $0.60 \pm 0.05 \mathrm{ppm}$ to $6.23 \pm 0.24 \mathrm{ppm}$ and BPA migration could not be detected in any of contact conditions. Estimated daily intakes of BPA via infant formula in PC baby bottle were calculated as $1.8 \mu \mathrm{g}$ $\mathrm{kg}^{-1}$ bw day ${ }^{-1}$ for a 3 month-old infant and $1.22 \mu \mathrm{g} \mathrm{kg}$ ${ }^{1}$ bw day ${ }^{-1}$ for a 6 month-old infant which was lower than but very close to the latest value of t-TDI $(4 \mu \mathrm{g} \mathrm{kg}$ 1 bw day $^{-1}$ ) determined by EFSA. Sterilization procedures changed the amount of residual BPA significantly. Although it is concluded that the use of
\end{abstract}

brand-new PC baby bottles does not pose a risk to health, sterilization procedures can lead to the higher amounts of migrated BPA which can be toxically important.

Keywords: Residual Bisphenol-A, BPA, HPLC, Method validation, Tolerable daily intake, Dietary exposure 
J ournal abbreviation: J Food Health Sci

\section{Introduction}

Polycarbonate (PC) is a widely used plastic in the production of food packaging or various materials in contact with food. PC material can be used in a number of consumer products including baby bottles and reusable water bottles (Maia et al., 2009; Üçüncü, 2007; Robertson, 2006; Kawamura et al., 1998). PC is derived from the bisphenol ester of carbonic acid and occurs as a result of condensation polymerization of Bisphenol A [2,2bis(4-hydroxyphenyl) propane] with carbonyl chloride or diphenyl carbonate. However, the unreacted residual Bisphenol-A (BPA) can be found in the material and migrate to the food from polycarbonate material.

BPA is a plastic monomer containing two phenol groups having high reactivity (Kawamura et al., 1998), and probably the most prominent regulated compound whose use in food contact materials was put into question in the recent years. Hundreds of toxicological studies were published on adverse effects of BPA, which was reported to act as an endocrine disruptor and causes developmental effects and changes in metabolism at low concentrations (Geueke, 2014). According to the report of NTP, there is a clear evidence of adverse developmental effects at "high" doses of BPA ( $>5$ $\mathrm{mg} \mathrm{kg}^{-1}$ bodyweight (bw) day ${ }^{-1}$ ) in laboratory animals, but there is scientific controversy over the interpretation of the "low" dose findings (NTP, 2008). BPA is attracting great attention due to being a chemical widely exposed by people as well as suspicious effects on reproductive and developmental systems in laboratory studies on animals. The studies on humans revealed that amount of BPA in the blood of people with health problems such as frequently recurrent miscarriages, abnormal karyotype in fetuses, obesity, endometrial hyperplasia, and polycystic ovarian syndrome was higher than the people without these cases (Vandenberg et al., 2007; Sugiura-Ogasawa et al., 2005; Takeuchi and Tsutsumi, 2002; Yamada et al., 2002). Therefore, it is necessary to be careful about residue levels and migration values in the PC material in contact with food and to make essential controls.

The data concerning the adverse effects of BPA on health have led to increase interest towards the migration of BPA from PC materials and there have been many studies on this issue. It is noteworthy that the majority of studies are related with PC baby bottles. As a result of literature review; amount of residual BPA in PC baby bottles may range from 5-10 ppb to $347 \mathrm{ppm}$ (Biedermann-Brem et al., 2008; Ehlert et al., 2008; Wong et al., 2005; Biles et al., 1997; Mountfort et al., 1997). In migration tests carried out under different conditions (temperature, incubation time), the amount of migrated BPA from PC baby bottles to distilled water was determined up to $13 \mathrm{ppb}$ level (Maragou et al., 2008; Davis et al., 2007; Kawamura et al., 1998; Hanai, 1997). These studies focused on the effect of temperature on BPA migration, but a simulated study on the daily use of the baby bottles has not been conducted, yet.

PC material can degrade as a result of repeated washing and sterilization procedures in the long term usage and this situation can lead to an increase in the amount of residual BPA in the PC material or in the migration levels of BPA in the food (Biederman-Brem and Grob, 2009; Sajiki and Yonekube, 2004; Brede et al., 2003). But in the literature there are some discrepancies concerning the effect of repetitive processes on BPA migration and residual amounts of BPA in PC material. It was stated that BPA migration did not increase with repetitive processes of sterilization with boiling water and brushing with detergent (Maragou et al., 2008) and process of sterilization with microwave (Ehlert et al., 2008); whereas, it was reported that the residual amount of BPA in PC material increased with process of sterilization with microwave (Biederman-Brem and Grob, 2009), process of sterilization with boiling water and process of brushing with detergent (Brede et al., 2003).

The aim of this study was (i) to make a general evaluation by performing residue analysis on the brand-new polycarbonate baby bottles, (ii) to determine the factors affecting the migration of BPA to the food by applying realistic contact conditions, and (iii) to investigate effects of repetitive processes of brushing with detergent, sterilization with boiling water, sterilization with microwave oven, and sterilization with baby bottle sterilizer on residual BPA.

\section{Legal status of BPA}

In Europe in 2002, BPA was authorized to be used as a monomer and an additive for the manufacturing of plastic materials and articles intended to come in contact with foodstuffs together with a specific migration limit of $0.6 \mathrm{mg}$ $\mathrm{kg}^{-1}$ food (Commission Directive, 2002/72/EC). 


\section{J ournal abbreviation: J Food Health Sci}

This Directive was amended in 2011, with a temporary ban on the use in the manufacturing of polycarbonate infant feeding bottles as from 1 March 2011 and the marketing of these feeding bottles as from 1 June 2011 (Commission Directive, 2011/8/EU). Since May 2011, Directive $2002 / 72 / \mathrm{EC}$ is replaced by Regulation No $10 / 2011 / \mathrm{EU}$, which has maintained the ban of BPA in polycarbonate infant feeding bottles and kept the current restriction for BPA as a monomer with a specific migration limit (SML) of $0.6 \mathrm{mg}$ $\mathrm{kg}^{-1}$ food but removed its authorization as an additive in plastic food contact materials and articles (Commission Regulation, No 10/2011).

BPA was evaluated for the first time in 1986 by the Scientific Committee for Food (SCF) for its use in plastic materials and articles intended to come into contact with foodstuffs. At that time, the Committee allocated a tolerable daily intake (TDI) of $50 \mu \mathrm{g} \mathrm{kg}^{-1}$ bw day ${ }^{-1}$ (EFSA, 2002).

EFSA re-evaluated BPA in 2002 for its use in food contact materials. The Panel's conclusions were based on the then available, extensive database on repeated-dose toxicity, reproductive and developmental toxicity of BPA in rodents and on comparison of toxicokinetics in primates including humans and rodents. The Panel concluded to derive a temporary TDI (t-TDI) of 10 $\mu \mathrm{g}$ BPA kg${ }^{-1}$ bw day ${ }^{-1}$ (EFSA, 2008; EFSA, 2006; EFSA, 2002).

EFSA completed its first full risk assessment of BPA in 2006 and revised a TDI of $50 \mu \mathrm{g} \mathrm{kg}^{-1}$ bw day $^{-1}$ for this substance. This is based on the noobserved-adverse-effect-level (NOAEL) of $5 \mathrm{mg}$ $\mathrm{kg}^{-1}$ bw day ${ }^{-1}$ that has been identified in two multigeneration reproductive toxicity studies in rodents, where the critical effects were changes in body and organ weights in adults and offspring rats and liver effects in adult mice, respectively (EFSA, 2006).

Since 2006, EFSA and its scientific panels have considered hundreds of scientific publications in peer-reviewed scientific journals as well as reports from studies submitted by industry. EFSA reviewed new scientific information on BPA in 2008, 2009, 2010 and 2011: on each occasion EFSA's experts concluded that they could not identify any new evidence which would lead them to revise the TDI for BPA of $50 \mu \mathrm{g} \mathrm{kg}^{-1}$ bw day (EFSA, 2015).

In the draft opinion dated January 2014, EFSA's Panel on Food Contact Materials, Enzymes,
Flavorings and Processing Aids (CEF) identified possible adverse effects on liver and kidney and effects on the mammary gland as being linked to exposure to the chemical. It is therefore recommended for the current TDI to be lowered from its current level of $50 \mu \mathrm{g} \mathrm{kg}^{-1}$ bw day ${ }^{-1}$ ) to 5 $\mu \mathrm{g} \mathrm{kg}^{-1}$ bw day ${ }^{-1}$ (EFSA, 2014). And t-TDI value was lowered to $4 \mu \mathrm{g} \mathrm{kg}^{-1}$ bw day ${ }^{-1}$ by EFSA CEF Panel as from January 2015 (EFSA, 2015).

\section{Materials and Methods}

\section{Chemicals and samples}

BPA (Pubchem CID:6623) standard (99\% purity) was purchased from Aldrich Chemical Co. (St.Louis, MO). Stock solution for residual BPA analysis was prepared by using methanol and standard working solutions for residual BPA analysis were in the range of $25-400 \mu \mathrm{g} \mathrm{L}^{-1}$. Stock solutions for migration analyses were prepared by using distilled water, $50 \%$ EtOH and 3\% acetic acid for migration of BPA. Standard working solutions for migration analyses were in the range of $10-100 \mu \mathrm{g} \mathrm{L}^{-1}$. Water, used as HPLC solvent, as simulant for the migration tests, and for preparation of BPA standard solutions, was purified with by using a Zeneer Power 1 (Human Corporation, Seoul-Korea).

For residue analysis of BPA, PC baby bottles from eight international brands were supplied from different companies. PC baby bottles from the trademark that was manufactured in Turkey were used for BPA migration analysis.

Identification of the material of baby bottles with FT-IR

The material of the baby bottles was subjected to infrared analysis to confirm that the material was polycarbonate. FT-IR measurements were carried out by using a Perkin-Elmer Spectrum 100 FT-IR spectrometer (Bucks, UK).

\section{Residual BPA analysis}

Total residual content of BPA in PC baby bottle was determined according to the method of Biles et al., (1997). $20 \mathrm{~mL}$ of dichloromethane was added in to $1 \mathrm{~g}$ portion of polymer. Beaker was placed in an ultrasonic water bath at ambient temperature and kept until the polymer was completely dissolved. The dissolved polymer was titrated with $50 \mathrm{~mL}$ of methanol. The polymer precipitate was allowed to settle for $10 \mathrm{~min}$. The supernatant was removed and filtered through a polytetrafluoroethylene (PTFE) filter of $0.45 \mu \mathrm{m}$ 


\section{J ournal abbreviation: J Food Health Sci}

pore size and analyzed by HPLC-FLD. Method validation procedure of residual BPA analysis was performed by examining linearity, limit of detection (LOD), limit of quantitation (LOQ), and repeatability (Rec).

\section{BPA migration analysis}

Migration analyses were performed after PC baby bottles were subjected to proper migration test conditions. PC baby bottles were contacted with food simulants by the filling method. Sample from the simulant was taken into the vial and analyzed by HPLC-FLD. Method validation procedure of BPA migration analysis was performed by examining linearity, limit of detection (LOD) and limit of quantitation (LOQ) for each food simulant.

\section{Design for migration analysis}

Migration of BPA from PC baby bottles was investigated at three filling temperatures with two storage temperatures and three contact times representing the realistic conditions of the use of baby bottles on three food types to determine the migration potentials of PC baby bottles.

Food simulants indicated in Commission Regulation No 10/2011: distilled water (representing aqueous food), 50\% ethanol (representing milk) and 3\% acetic acid (v/v) aqueous solution (representing fruit juice) were used as food simulants for the migration testing.

I. Contact conditions: $5^{\circ} \mathrm{C}$ and $22^{\circ} \mathrm{C}$ were chosen for representing refrigerator temperature and room temperature, respectively.

II. Contact conditions: $40^{\circ} \mathrm{C}, 60^{\circ} \mathrm{C}$ and $80^{\circ} \mathrm{C}$ were chosen for representing hot filling. Baby bottles were filled at these temperature values and then stored at room temperature.

BPA migration analysis was carried out at $0.5,12$ and 24 hours of contact.

\section{Design for repetitive procedures}

Following treatments were applied to baby bottles for simulation and residual BPA content of PC material was analyzed before treatment (initial amount of BPA) and at $10^{\text {th }}, 30^{\text {th }}$ and $50^{\text {th }}$ cycles of treatments.

Brushing with detergent (APP1): Baby bottles were washed with tap water at $45^{\circ} \mathrm{C}$ with a standardized procedure and then left for drying for 10 minutes in each cycle.

Sterilization with boiling water (APP2): Baby bottles were sterilized for 5 minutes and then left for drying for 10 minutes in each cycle.

Sterilization with microwave oven (APP3): Baby bottles were sterilized for 5 minutes and then left for drying for 10 minutes in each cycle.

Sterilization in baby bottle sterilizer (APP4): Baby bottles were sterilized for 5 minutes and then left for drying for 10 minutes in each cycle.

\section{Chromatographic parameters}

Chromatographic separations were carried out by using an Agilent 1200 Series HPLC system (Santa Clara, United States). HPLC conditions employed were as follows:

Mobile phase: methanol/water $(70: 30, \mathrm{v} / \mathrm{v})$ was used in isocratic elution mode,

Flow rate for analysis: $0.4 \mathrm{~mL} / \mathrm{min}$,

Analytical column: Zorbax Eclipse XDB $\mathrm{C}_{18}$ $(150 \mathrm{~mm} \times 4.6 \mathrm{~mm}$ i.d. $)$,

Temperature: $25^{\circ} \mathrm{C}$,

Injection volume was $10 \mu \mathrm{l}$ for all the solutions,

Fluorescent detection at Ex: 225, 235 and $285 \mathrm{~nm}$ and at Em:315 nm)

\section{Statistical analysis}

The data of residual content of BPA were statistically analyzed and presented as the mean \pm standard deviation (SD). The coefficient of determination $\left(\mathrm{r}^{2}\right)$ was determined by regression/ correlation analysis in the SPSS software (IBM, PASW Statistics 19, USA). Statistical significance was performed using one-way ANOVA and Duncan's multiple range tests $(\mathrm{p} \leq 0.05)$.

\section{Results and Discussion}

\section{Method validation of total residual content}

Standard working solutions were prepared in methanol. Calibration curves were obtained by measuring standard working solutions at five levels in the range of $25-400 \mu \mathrm{g} \mathrm{L}^{-1}$ with three replicates per concentration. Linear regression analysis was performed using the analyte peak area vs. analyte concentration $\left(r^{2}>0.99\right)$ (Figure 1). Limit of detection (LOD) and limit of quantification (LOQ) were determined as 33.75 $\mathrm{ppb}$ and $54.15 \mathrm{ppb}$, respectively (Table 1). 
Recovery was determined as $100.41 \%$. Figure 2 shows a chromatogram of residual BPA in sample of PC baby bottle.

\section{Method validation of migration analysis}

Method validation was carried out for each food simulant. Standard working solutions were prepared by using distilled water, $50 \%$ ethanol, and $3 \%$ acetic acid. Calibration curves were obtained by measuring standard working solutions at five levels in the range of $10-100 \mu \mathrm{g} \mathrm{L}^{-1}$ with three replicates per concentration. The coefficient of determination $\left(\mathrm{r}^{2}\right)$ of the obtained calibration curve was found as $>0.99$. Table 1 shows LOD and LOQ values for each food simulant. Figure 3 shows chromatograms of BPA for each food simulant.

\section{Residue analysis}

Residue analyses were performed on samples of PC baby bottles supplied from eight companies. As a result of these tests, different amounts of residual BPA were determined (Table 2). While the highest amount of residual BPA was 6.23 $\pm 0.24 \mathrm{ppm}$, the lowest amount was $0.60 \pm 0.05$ ppm.

Different amounts of residual BPA in PC baby bottles are found in the literature and these values range from 5-10 ppb levels to $141 \mathrm{ppm}$ (Table 3). While considering the results of these studies, baby bottles analyzed from different international companies were not too high and had relatively standard quality in terms of levels of residual BPA.

\section{Migration analysis}

As a result of migration analyses performed under contact condition I $\left(5^{\circ} \mathrm{C}\right.$ and $22^{\circ} \mathrm{C}$ of storage temperatures) and contact condition II $\left(40^{\circ} \mathrm{C}\right.$, $60^{\circ} \mathrm{C}$, and $80^{\circ} \mathrm{C}$ of filling temperatures), the migrated BPA could not be detected in any of the contact conditions. This result showed that amount of migrated BPA under these contact conditions was below the specified limit of detection value of the method for each simulant shown in Table 1.

As a result of literature review, it was observed that BPA migration varied from 3 to $55 \mu \mathrm{g} \mathrm{L}^{-1}$ (LOD was $2 \mu \mathrm{g} \mathrm{L}^{-1}$ ) in PC baby bottles filled with boiling water $\left(95^{\circ} \mathrm{C}\right)$ and kept overnight at room temperature (Hanai, 1997). In another study, any BPA migration was not specified from PC baby bottles that were contacted with distilled water at $60^{\circ} \mathrm{C}$ for 30 minutes but $0,5 \mathrm{ppb}$ of BPA was detected when they performed the same test at $95^{\circ} \mathrm{C}$ of contact temperature (Kawamura et al., 1998). Other researchers analyzed the migration of BPA from PC baby bottles filled with boiling water and left at ambient temperature for $45 \mathrm{~min}$. The migration values of BPA ranged between 2.4$14.3 \mu \mathrm{g} \mathrm{L}^{-1}$ (LOD is $2.4 \mu \mathrm{g} \mathrm{L}^{-1}$ ) (Maragou et al., 2008). In a study conducted in the UK by Central Test Laboratory, BPA migration tests were performed on PC baby bottles. Half an hour contact at $70^{\circ} \mathrm{C}$ was applied with $10 \%$ ethanol and $3 \%$ acetic acid. No migration was detected (LOD was $1.1 \mu \mathrm{g} \mathrm{L}^{-1}$ for $10 \%$ ethanol and $0.3 \mu \mathrm{g} \mathrm{L}^{-1}$ for $3 \%$ acetic acid) (CSL, 2004). Although limit of detection was very low, migration of BPA was not detected in this study as in the present study. In a migration study conducted with five baby bottle brands in America and Canada, BPA migration was not determined from PC baby bottles left at ambient temperature for 24 hours; whereas, 5-8 ppb of BPA migration was reported when the contact temperature was increased to $80^{\circ} \mathrm{C}$ for 24 hours (Davis et al., 2007).

According to these results, when the LOD value of $10.40 \mathrm{ppb}$ for $50 \%$ ethanol (the simulant of infant formula) was considered as the maximum migration value, the daily intakes of BPA estimated via infant formula in PC baby bottle can be calculated as follows: (The food consumption scenario was taken from EFSA, 2006 based on the German DONALD study by Kersting, 1998) (EFSA, 2006).

$\checkmark$ For a 3 month-old infant having a weight of $6.1 \mathrm{~kg}$ and consuming $174 \mathrm{~mL} \mathrm{~kg}^{-1}$ bw of infant formula via PC baby bottle, the daily intake of BPA estimated from our results was $1.8 \mu \mathrm{g} \mathrm{kg}^{-1}$ bw day ${ }^{-1}$.

$10.40 \mu \mathrm{g} \mathrm{L} \mathrm{L}^{-1}$ (LOD) $\times 1.061 \mathrm{~L}$ (daily consumption amount of infant formula for an infant having a weight of $6.1 \mathrm{~kg}$ ) $/ 6.1 \mathrm{~kg}$ (weight of infant) $=1.8 \mu \mathrm{g} \mathrm{kg}^{-1} \mathrm{bw} \mathrm{day}^{-1}$,

$\checkmark$ For a 6 month-old infant having a weight of $7.8 \mathrm{~kg}$ and consuming $118 \mathrm{~mL} \mathrm{~kg}^{-1}$ bw of infant formula, the daily intake of BPA estimated from our results was $1.22 \mu \mathrm{g} \mathrm{kg}^{-1}$ bw day ${ }^{-1}$. 
Journal of Food and Health Science, 3(4): 150-160 (2017)

J ournal abbreviation: J Food Health Sci

(a)

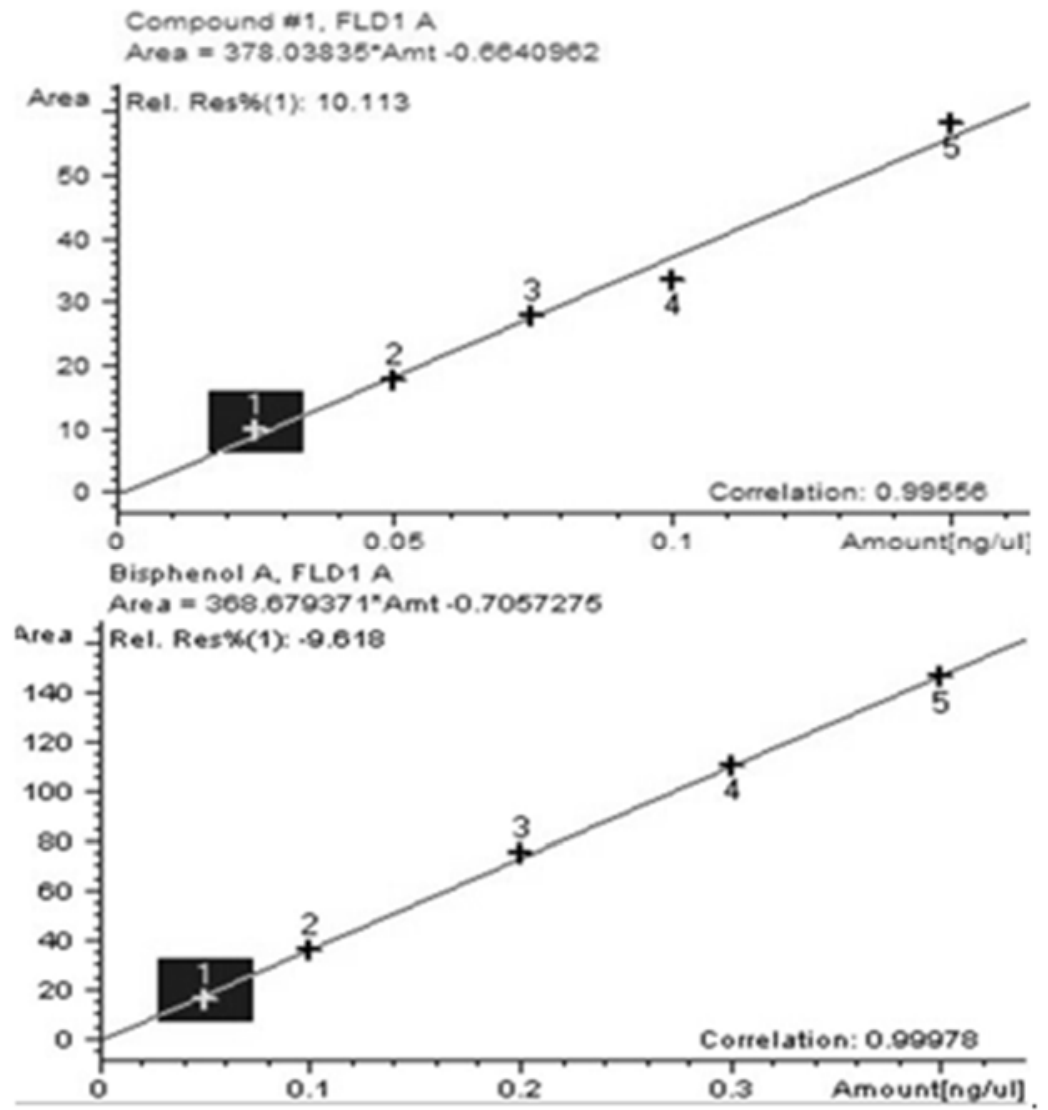

Figure 1. Calibration curves used in BPA residue analysis (a) $25-150 \mu \mathrm{g}^{-1}$ standard solution (b) 50$400 \mu \mathrm{g} \mathrm{l}^{-1}$ standard solution.

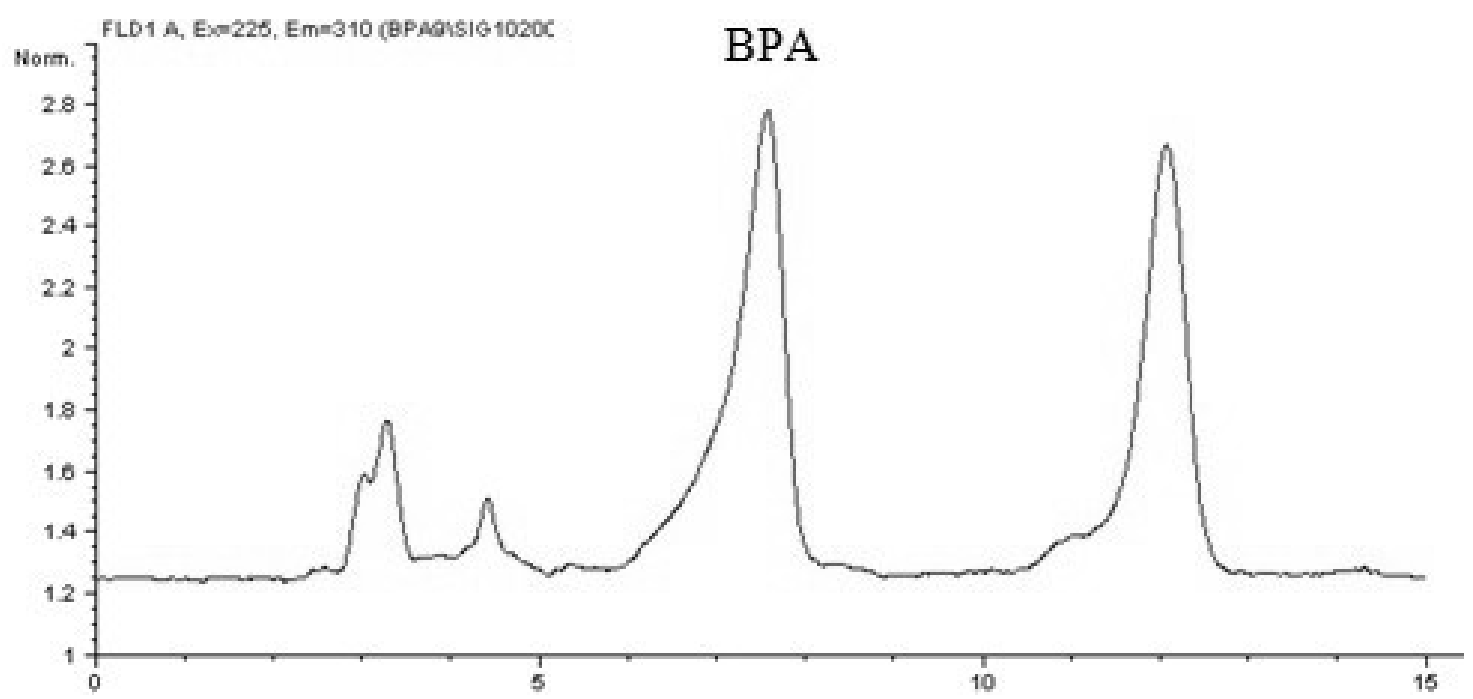

Figure 2. Chromatogram of BPA residue in PC baby bottle sample. 
Journal of Food and Health Science, 3(4): 150-160 (2017)

J ournal abbreviation: J Food Health Sci

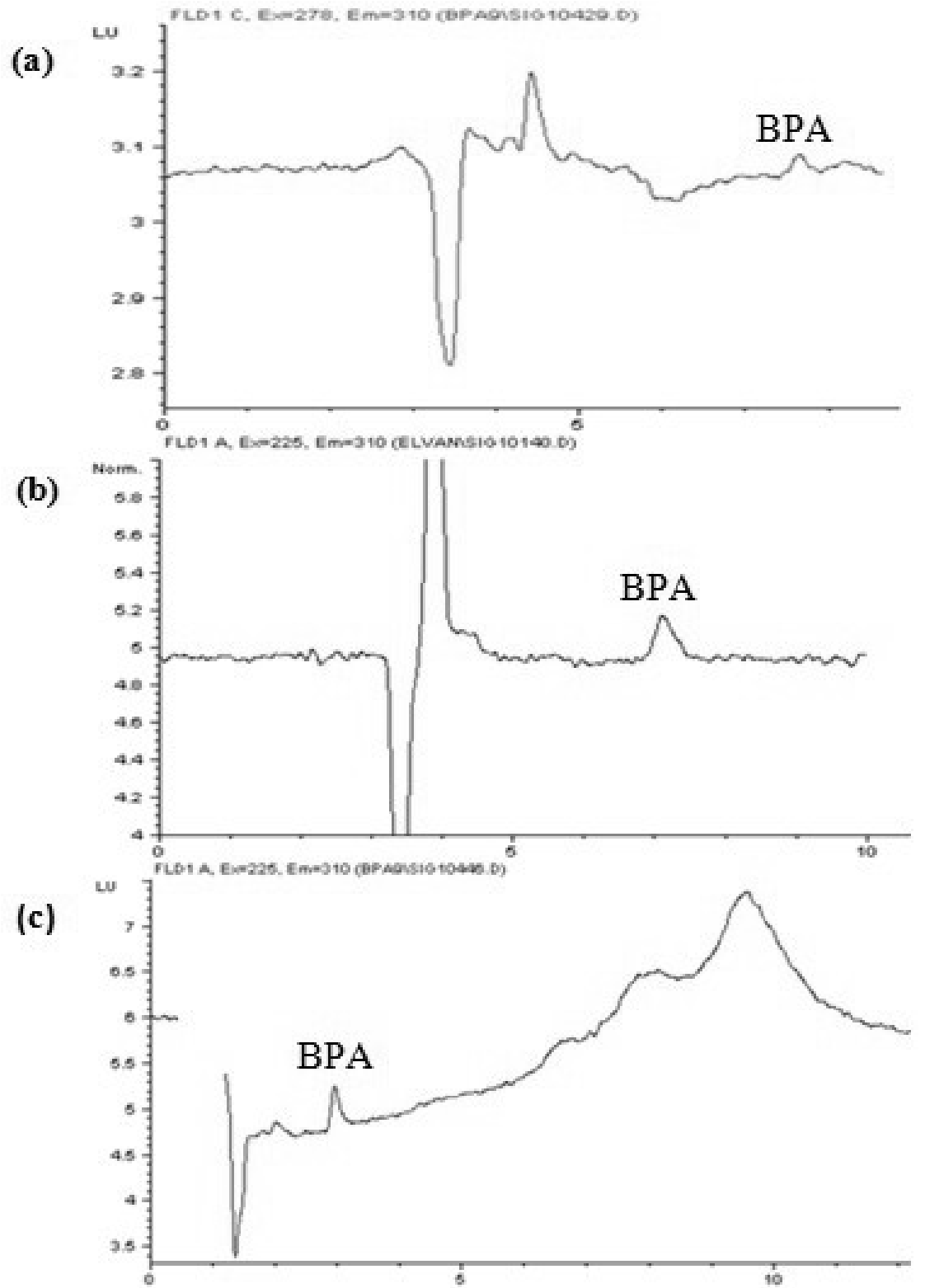

Figure 3. Chromatograms of (a) 12,5 ppb BPA in distilled water, (b) $10 \mathrm{ppb}$ BPA in $50 \%$ ethanol and (c) 1 pbb BPA in $3 \%$ acetic acid.

Table 1. Limit of detection and limit of quantification values of BPA migration analysis for different food simulants and residual BPA analysis

\begin{tabular}{lll}
\hline & $\begin{array}{l}\text { LOD } \\
(\mathrm{ppb})\end{array}$ & $\begin{array}{l}\text { LOQ } \\
(\mathrm{ppb})\end{array}$ \\
\hline Distilled water & 15.10 & 26.90 \\
$50 \%$ ethanol & 10.40 & 11.34 \\
$3 \%$ acetic acid & 1.30 & 2.00 \\
Residue analysis & 33.75 & 54.15 \\
\hline
\end{tabular}


J ournal abbreviation: J Food Health Sci

Table 2. The detected amount of residual BPA in PC baby bottles belong to different firms

\begin{tabular}{|c|c|c|}
\hline Brand number & $\begin{array}{l}\text { Residual content } \\
(\mathrm{ppm})\end{array}$ & \\
\hline 1 & $1.75 \pm 0.15^{\mathrm{b}}$ & \\
\hline 2 & $6.23 \pm 0.24^{\mathrm{d}}$ & \\
\hline 3 & $0.60 \pm 0.05^{\mathrm{a}}$ & \\
\hline 4 & $5.76 \pm 1.08^{\mathrm{d}}$ & \\
\hline 5 & $2.20 \pm 0.40^{\mathrm{c}}$ & \\
\hline 6 & $2.79 \pm 1.36^{\mathrm{c}}$ & \\
\hline 7 & $1.95 \pm 0.60^{\mathrm{b}}$ & \\
\hline 8 & $2.10 \pm 0.10^{\mathrm{c}}$ & \\
\hline \multicolumn{3}{|c|}{$\begin{array}{l}\text { Means within each column followed by different letters are significantly different at } \mathrm{p} \leq 0.05 \text {. } \\
\text { Table 3. Residual BPA amounts of PC baby bottles in different studies. }\end{array}$} \\
\hline Reference & Material type & $\begin{array}{l}\text { Amount of BPA resi- } \\
\text { due }\end{array}$ \\
\hline Ehlert et al., 2008 & PC baby bottle & $1.4-35.3 \mathrm{ppm}$ \\
\hline Biedermann-Brem et al., 2008 & PC baby bottle & $6-25 \mathrm{ppb}$ \\
\hline Wong et al., 2005 & PC baby bottle & 4.01-141 ppm \\
\hline Biles et al., 1997 & PC baby bottle & $7-58 \mathrm{ppm}$ \\
\hline Mountforth et al., 1997 & PC baby bottle & $18-139 \mathrm{ppm}$ \\
\hline Nam et al., 2010 & PC baby bottle & $16.2-17.6 \mathrm{ppm}$ \\
\hline IAT, 2007 & PC baby bottle & $5-10 \mathrm{ppb}$ \\
\hline
\end{tabular}

$10.40 \mu \mathrm{g} \mathrm{L}^{-1}$ (LOD) x $0.920 \mathrm{~L}$ (daily consumption amount of infant formula for an infant having a weight of $7.8 \mathrm{~kg}$ ) $/ 7.8 \mathrm{~kg}$ (weight of infant) $=1.22$ $\mu \mathrm{g} \mathrm{kg}^{-1}$ bw day ${ }^{-1}$

When we considered that the amount of BPA migrated from analyzed baby bottles to $50 \%$ ethanol was equal to the LOD value of $10.40 \mathrm{ppb}$, this assessment on infant dietary exposure to BPA from PC baby bottles in the present study was lower than the dietary estimates for infants presented in opinion of EFSA (2006) as shown in Table 4 and also was lower than the latest value of t-TDI $\left(4 \mu \mathrm{g} \mathrm{kg}^{-1}\right.$ bw day $\left.{ }^{-1}\right)$ determined by EFSA (2015).

\section{Effect of repetitive procedures:}

As a result of repetitive procedures as it was seen from Table 5, it was found that; brushing with detergent procedure (APP1) did not change the amount of residual BPA in PC material and it varied between $1.30 \pm 0.05 \mathrm{ppm}$ and $1.50 \pm 0.48$ ppm amongst all cycles. Sterilization with boiling water procedure (APP2) significantly $(\mathrm{p} \leq 0.5)$ affected the residual BPA amount in PC material at each cycle from $1.38 \pm 0.46 \mathrm{ppm}$ to $10.03 \pm 0.93$ ppm. Sterilization in microwave (APP3) significantly $(\mathrm{p} \leq 0.5)$ affected the residual BPA amount especially at $50^{\text {th }}$ cycle of procedures whereas there was no significant change in first two cycles. It varied from $1.28 \pm 0.04 \mathrm{ppm}$ to 3.54 $\pm 0.56 \mathrm{ppm}$. Sterilization in baby bottle sterilizer procedure (APP4) significantly $(\mathrm{p} \leq 0.5)$ affected the amount of residual BPA for each cycle of the treatment from $1.33 \pm 0.07 \mathrm{ppm}$ to $11.59 \pm 0.54$ ppm. It can be concluded that brushing process does not give any wearing affect to the bottles to increase the residual BPA amount. In contrast to this all of the sterilization processes leaded to the increase in residual BPA amount in PC baby bottles. PC material can be degraded as a result of contact with high temperature water in boiling water or in microwave sterilization procedures or with saturated water in baby bottle sterilizer. Thus, as it was stated by Bidermann-Brem and Grob (2009), when the tap water boiled the degassing of carbon dioxide causes the $\mathrm{pH}$ to increase and form a far more aggressive medium. The high $\mathrm{pH}$ combined with a high temperature can lead to degradation of PC material. It was also stated by Sajiki and Yonekubo (2004) that basic pH provokes the degradation of PC material leading 
J ournal abbreviation: J Food Health Sci

to the increased migration values from the material.

Table 4. Estimates of total dietary exposure to BPA for infants (EFSA, 2006).

\begin{tabular}{|c|c|c|}
\hline Age of consumer & Food/beverage consumed & $\begin{array}{l}\text { Dietary exposure to BPA } \\
\left(\mu \mathrm{g} \mathrm{kg}^{-1} \text { bw day }{ }^{-1}\right)\end{array}$ \\
\hline 3 mounths infant & Infant formula fed with PC bottle & 11 \\
\hline 6 mounts infant & $\begin{array}{l}\text { Infant formula fed with PC bottle } \\
\text { and commercial food/beverages }\end{array}$ & 13 \\
\hline
\end{tabular}

Table 5. Effect of repetitive procedures on the amounts of residual BPA

\begin{tabular}{|c|c|}
\hline Repetative procedure & Amount of residual BPA (ppm) \\
\hline APP1 initial & $1.30 \pm 0.05^{\mathrm{a}}$ \\
\hline APP $110^{\text {th }}$ cycle & $1.31 \pm 0.06^{\mathrm{a}}$ \\
\hline APP1 $30^{\text {th }}$ cycle & $1.40 \pm 0.02^{b}$ \\
\hline APP $150^{\text {th }}$ cycle & $1.50 \pm 0.48^{\mathrm{c}}$ \\
\hline APP2 initial & $1.38 \pm 0.46^{\mathrm{a}}$ \\
\hline APP2 $10^{\text {th }}$ cycle & $7.23 \pm 0.41^{b}$ \\
\hline APP2 $30^{\text {th }}$ cycle & $8.56 \pm 0.15^{\mathrm{c}}$ \\
\hline APP2 $50^{\text {th }}$ cycle & $10.03 \pm 0.93^{\mathrm{d}}$ \\
\hline APP3 initial & $1.28 \pm 0.04^{\mathrm{a}}$ \\
\hline APP3 $10^{\text {th }}$ cycle & $1.12 \pm 0.07^{\mathrm{a}}$ \\
\hline APP3 $30^{\text {th }}$ cycle & $1.60 \pm 0.02^{\mathrm{a}}$ \\
\hline APP3 $50^{\text {th }}$ cycle & $3.54 \pm 0.56^{\mathrm{b}}$ \\
\hline APP4 initial & $1.33 \pm 0.07^{\mathrm{a}}$ \\
\hline APP4 $10^{\text {th }}$ cycle & $3.59 \pm 0.38^{b}$ \\
\hline APP4 $30^{\text {th }}$ cycle & $4.78 \pm 0.53^{b c}$ \\
\hline APP4 $50^{\text {th }}$ cycle & $11.59 \pm 0.54^{\mathrm{c}}$ \\
\hline
\end{tabular}

Means within each column followed by different letters are significantly different at $\mathrm{p} \leq 0.05$.

APP1: Brushing with detergent procedure; APP2: Sterilization with boiling water procedure; APP3: Sterilization in microwave procedure; APP4: Sterilization in baby bottle sterilizer procedure

\section{Conclusion}

This study showed that PC baby bottles can be produced with different amounts of the residual BPA ranging from $0.60 \pm 0.05 \mathrm{ppm}$ to $6.23 \pm 0.24$ ppm and the BPA residue was inevitable in PC baby bottle production. Migration of BPA from brand-new PC baby bottle to $50 \% \mathrm{EtOH}$ was far below the specific migration limit of BPA. But for the compounds posing a health risk like BPA, it should be toxicologically evaluated. Although the tolerable daily intake of BPA has been varied too much within the years, it was lowered to $4 \mu \mathrm{g} \mathrm{kg}$ ${ }^{1}$ bw day ${ }^{-1}$ by EFSA in the year of 2015 . Although the migrated amount of BPA was below its t-TDI value, it was very close to it.

It was seen that as the PC baby bottles were used in daily life with washing and sterilization treatments, the processes of sterilization with boiling water, microwave, and steam sterilizer changed the amount of residual BPA significantly which will lead to higher amounts of migrated BPA. But the washing treatment by brushing with detergent did not change the residual BPA amount significantly.

Although it was concluded that the use of brandnew PC baby bottles will not pose a risk to health, the amount of residual BPA will increase with the effect of sterilization processes which are the necessary treatments for the use of baby bottles for infants under the age of 1 . And these processes will lead to the higher amounts of migrated BPA which can be toxically important. 


\section{J ournal abbreviation: J Food Health Sci}

\section{Acknowledgement}

The authors thank to the Fund of Scientific Research Projects of Ege University with project number of 2010/MUH/053.

\section{References}

Biedermann-Brem, S. \& Grob, K. (2009). Release of Bisphenol A from polycarbonate baby bottles: water hardness as the most relevant factor. European Food Research Technology, 228, 679-684.

Biedermann-Brem, S., Grob, K. \& Fjeldahl, P. (2008). Release of bisphenol A from polycarbonate baby bottles: mechanism of formation and investigation of worst case scenarios. European Food Research Technology, 227, 1053-1060.

Biles, J.E., McNeal, T.P., Begley, T.H. \& Hollifield, H.C. (1997). Determination of bisphenol-a in reusable polycarbonate food-contact plastics and migration to food-simulating liquids. Journal of Agricultural and Food Chemistry, 45, 3541-3544.

Brede, C., Fjeldal, P., Skjevrak, I. \& Herikstad, H. (2003). Increased migration levels of Bisphenol A from polycarbonate baby bottles after dishwashing, boiling and brushing conditions. Food Additives and Contaminants, 20(7), 684-689.

CSL (Central Science Laboratory). (2004). A study of the migration of bisphenol A from polycarbonate feeding bottles into food simulants. Central Science Laboratory Test Report L6BB-1008 for the Boots Group.

Commission Directive. 2002/72/EC. (2002). Relating to plastic materials and articles intended to come into contact with foodstuffs. Official Journal of the European Communities, L 220/ 27.

Commission Directive. 2011/8/EU. (2011). Amending Directive 2002/72/EC as regards the restriction of use of Bisphenol A in plastic infant feeding bottles. Official Journal of the European Communities, L 26/ 11.

Commission Regulation. No 10/2011. (2011). Plastic materials and articles intended to come into contact with food. Official Journal of the European Communities, L 12/1.

Council Directive. 85/572/EEC. (1985) .The list of simulants to be used for testing migration of constituents of plastic materials and articles intended to come into contact with foodstuffs. Official Journal of the European Communities, L 372 /14

Davis, M., Fould, J., Freeman, A., Khatter, K., Polyzou, C., Robinson, J., Schade, M., Smith, R. \& Vom Saal, F. (2007). Baby's Toxic Bottle: Bisphenol a leaching from popular baby bottles. Columbia: University of Missouri.

Ehlert, K.A., Beumer, C.W.E. and Groot, M.C.E. (2008). Migration of bisphenol A into water from polycarbonate baby bottles during microwave heating. Food Additives and Contaminants A, 25(7), 904-910.

EFSA (European Food Safety Authority). (2002). Opinion of the scientific committee on food on Bisphenol A.

EFSA (European Food Safety Authority). (2006). Opinion of the scientific panel on food additives, flavourings, processing aids and materials in contact with food (AFC) related to 2,2-bis(4-hydroxyphenyl)propane (Bisphenol A). EFSA Journal, 428, 1-75.

EFSA (European Food Safety Authority). (2008). Toxicokinetics of bisphenol a: scientific opinion of the panel on food additives, flavourings, processing aids and materials in contact with food (AFC). EFSA Journal, $759,1-10$.

EFSA (European Food Safety Authority). (2014). Draft scientific opinion on the risks to public health related to the presence 2 of bisphenol A (BPA) in foodstuffs: EFSA panel on food contact materials, enzymes, flavourings and processing aids.

EFSA (European Food Safety Authority). (2015). Scientific Opinion on the risks to public health related to the presence of bisphenol A (BPA) in foodstuffs: Executive summary. EFSA panel on food contact materials, enzymes, flavourings and processing aids.

Geueke, B., Wagner, C.C. \& Muncke, J. (2014). Food contact substances and chemicals of concern: a comparison of inventories. Food Additives and Contaminants A, 33, 14381450. 
J ournal abbreviation: J Food Health Sci

Hanai, Y. (1997). Bisphenol-A eluted from nursing bottles. Unpublishing data. Enviromental Science Research Center. Yokohama National University.

IBM Corp. Released 2010. IBM SPSS Statistics for Windows, Version 19.0. Armonk, NY: IBM Corp.

IAT (Institute for Agricult. and Trade Policy), (2007), Toxic Chemical Leaches from Popular Baby Bottles

Kawamura,Y., Koyama,Y., Takeda, Y. \& Yamada T. (1998). Migration of bisphenol-A from polycarbonate products. Journal of the Food Hygienic Society of Japan, 39, 206212.

Maia, J., Cruz, J.M., Sendon, R., Bustos J., Sanchez J.J. \& Paseiro P. (2009). Effect of detergents in the release of bisphenol a from polycarbonate baby bottles. Food Research International, 42, 1410-1414.

Maragou, N.C., Marki, A., Lampi, E.N., Thomaidis, N.S. \& Koupparis M.A. (2008). Migration of bisphenol A from poycarbonate baby bottles under real use conditions. Food Additives and Contaminants, 25(3), 373383.

Mountfort, K.A., Kelly, J., Jickells, S.M. \& Castle, L. (1997). Investigations in to the potential degradation of polycarbonate baby bottles during sterilization with consequent release of Bisphenol A. Food Additives and Contaminants, 14 (6-7), 737-740.

NTP (National Toxicology Program). (2008). NTP-CERHR Monograph on the Potential Human Reproductive and Developmental Effects of Bisphenol A. Center for the Evaluation of Risks to Human Reproduction. NIH Publication No: 08-5994.
Robertson, G.L. (2006). Food packaging: principles and practice. Boca Raton: Taylor and Francis. p. 9-42.

Sajiki, J., Yonekubo, J. (2004). Leaching of Bisphenol A (BPA) from polycarbonate plastic to water containing amino acids and its degradation by radical oxygen species. Chemosphere, 55, 861-867.

Sugiura-Ogasawara, M., Ozaki, Y., Sonta, S.I., Makino, T. \& Suzumori, K. (2005). Exposure to bisphenol A is associated with recurrent miscarriage. Human Reproduction, 20, 2325-2329.

Takeuchi, T. \& Tsutsumi, O. (2002). Serum bisphenol A concentrations showed gender differences, possibly linked to androgen levels. Biochemical and Biophysical Research Communications, 291, 76-78.

Üçüncü, M. (2007). Plastikler ve Plastik Esaslı Ambalaj Materyalleri. In Üçüncü, M. (Ed). Gıda Ambalajlama Teknolojisi. p. 328-329. İzmir: Meta Basım Matbaacıllı Hizmetleri.

Vandenberg, N., Hauser, R., Marcus, M., Olea, N. \& Wade, W. (2007). Human exposure to bisphenol A (BPA). Reproductive Toxicology, 24, 139-177.

Wong, K.O., Leo, L.W. \& Seah, H.L. (2005). Dietary exposure assessment of infants to bisphenol A from the use of polycarbonate baby milk bottles. Food Additives and Contaminants A, 22(3), 280-288.

Yamada, H., Furuta, I., Kato, E.H., Kataoka, S., Usuki, Y. \& Kobashi, G. (2002). Maternal serum and amniotic fluid bisphenol A concentrations in the early second trimester. Reproductive Toxicology, 16, 735-739. 